\title{
Analysis of Start, End and Length of the Growing Season and the Number of Rainy Days in Semi-Arid Central Rift Valley of Ethiopia
}

\author{
Lupi $\mathrm{A}^{*}$ and Mamo G
}

Ethiopia Institute of Agriculture Research, Melkassa Agriculture Research Center, Ethiopia

${ }^{*}$ Corresponding author: Lupi A, Ethiopia Institute of Agriculture Research, Melkassa Agriculture Research Center, P. o. Box 436 Adama, Oromia, Ethiopia, Tel: +25122220225, E-mail: agere97@gmail.com

Citation: Lupi A, Mamo G (2019) Analysis of Start, End and Length of the Growing Season and the Number of Rainy Days in Semi-Arid Central Rift Valley of Ethiopia. J Horti Sci \& Crop Res 1(1): 103

Received Date: July 20, 2018 Accepted Date: May 17, 2019 Published Date: May 19, 2019

\begin{abstract}
Ethiopian agriculture is dominated by smallholder farmers with an average per capita land holding of less than a hectare in which the production system mainly depends on rain fed. In order to characterize the climate of Mieso, Melkassa, and Adami Tulu located in Central rift valley (CRV) of Ethiopia. The daily weather data were obtained from MARC station and used for characterization using interactive statically (INSTAT) V3.37.The mean start, end and length of growing season are found to be May 26, September 14, and 99 days at Mieso site; May 27, October1st and 97 days at Melkassa site and whereas May 26, September 11, and 109 days in Adami Tulu site. The rainy days ranged from 92-165, 92-147, and 92-110 days in Mieso, Melkassa and Adami Tulu, respectively. From the results obtained there might be a clear message that the SOS, EOS, LGP and number of rainy days at the three stations is highly variable and, thus, needs a more attentions on different agronomic practice and genetic managements of crop variety. If these are not put in place, the sustainability of crop production and, thus, the efforts of ensuring food security in the CRV of the country will be jeopardized

Keywords: Start, End and Length of Growing Season and the Number of Rainy Days, Climate Variability
\end{abstract}

\section{Introduction}

Agriculture is the backbone of the Ethiopian economy. It is also the source of income for about $80 \%$ of the labor force in Ethiopia [1-4]. However, Ethiopian agriculture is dominated by smallholder farmers with an average per capita land holding of less than a hectare. The production system mainly depends on rain fed and low input including fertilizer and pesticides used The major source of water for low productivity agriculture in Ethiopia is natural rainfall .Assessing seasonal rainfall characteristics based on past records is essential to evaluate drought risk and to contribute to development of drought mitigation strategies

The variability of rainfall onset, cessation and duration affect planting (sowing) dates, crop growth, and yield and food production $[5,6]$. If a long dry spell follows, the seedlings die a "false start" and often lead to be resewn. According to Segele and Lamb (2005) reports, the major causes of agricultural failure in rift valley of Ethiopia are frequent dry spells of about 10 days length, as well as a shorter growing period due to replanting or late onset and/or early cessation of rain [7-10]. Reliable estimation of onset, cessation of rain and length of growing season could help optimize agricultural productivity strategies in semi-arid areas [7-9,11].

Climate variability, particularly rainfall variability and associated droughts, have been major causes of food insecurity and famine in Ethiopia [12-14]. To recap, characterization of rainfall onset, cessation, length of growing period and the number of rainy days is very important where the livelihood of people depend on agriculture and agriculture in turn depends on rainfall pattern [15]. Therefore, the main objectives of this paper are to explore the start, end and length of growing season and the number of rainy days of the Melkassa(1977-2013), Mieso(1973-2012) and Adami Tulu(1973-2012) areas in semi-arid CRV of Oromia state, Ethiopia

\section{Material and Methods}

\section{Descriptions of the Study Areas}

The areas under the study were in central rift valley of Ethiopia in regional state of Oromia The first study site is Melkassa near to Adama about $115 \mathrm{~km}$ from Addis Ababa. The second study site is Adami Tulu located at $160 \mathrm{~km}$ to south east of Addis Ababa. The 
third study site is Mieso located to the east of Addis Ababa at about of $300 \mathrm{~km}$. The soil type at the study site is a well-drained silty clay loam soil largely developed from volcanic parent material. Crops grown in the area include maize (Zea mays L.), sorghum (Sorghum bicolor), teff (Eragrostis teff), and other cereals, pulses, and oil crops (Table 1) (Figure 1).

\begin{tabular}{|c|c|c|c|c|c|c|c|}
\hline \multirow{2}{*}{ Station } & \multirow{2}{*}{ Region } & \multirow{2}{*}{ Zone } & \multicolumn{3}{|c|}{ Geographical coordination } & \multirow{2}{*}{ Data periods } & \multirow{2}{*}{$\begin{array}{c}\text { Duration of } \\
\text { the dataset(year) }\end{array}$} \\
\hline & & & Latitude(N) & Longitude(E) & Altitude(m) & & \\
\hline Melkassa & Oromia & East shoa & 8024 & 39012 & 1550 & $1977-2013$ & 36 \\
\hline Mieso & Oromia & West haraghe & 8048 & 4009 & 1470 & 1973-2012 & 39 \\
\hline Ademi Tulu & Oromia & East shoa & 7052 & 38043 & 1640 & 1973-2012 & 39 \\
\hline
\end{tabular}

Table 1: Description of the selected study areas

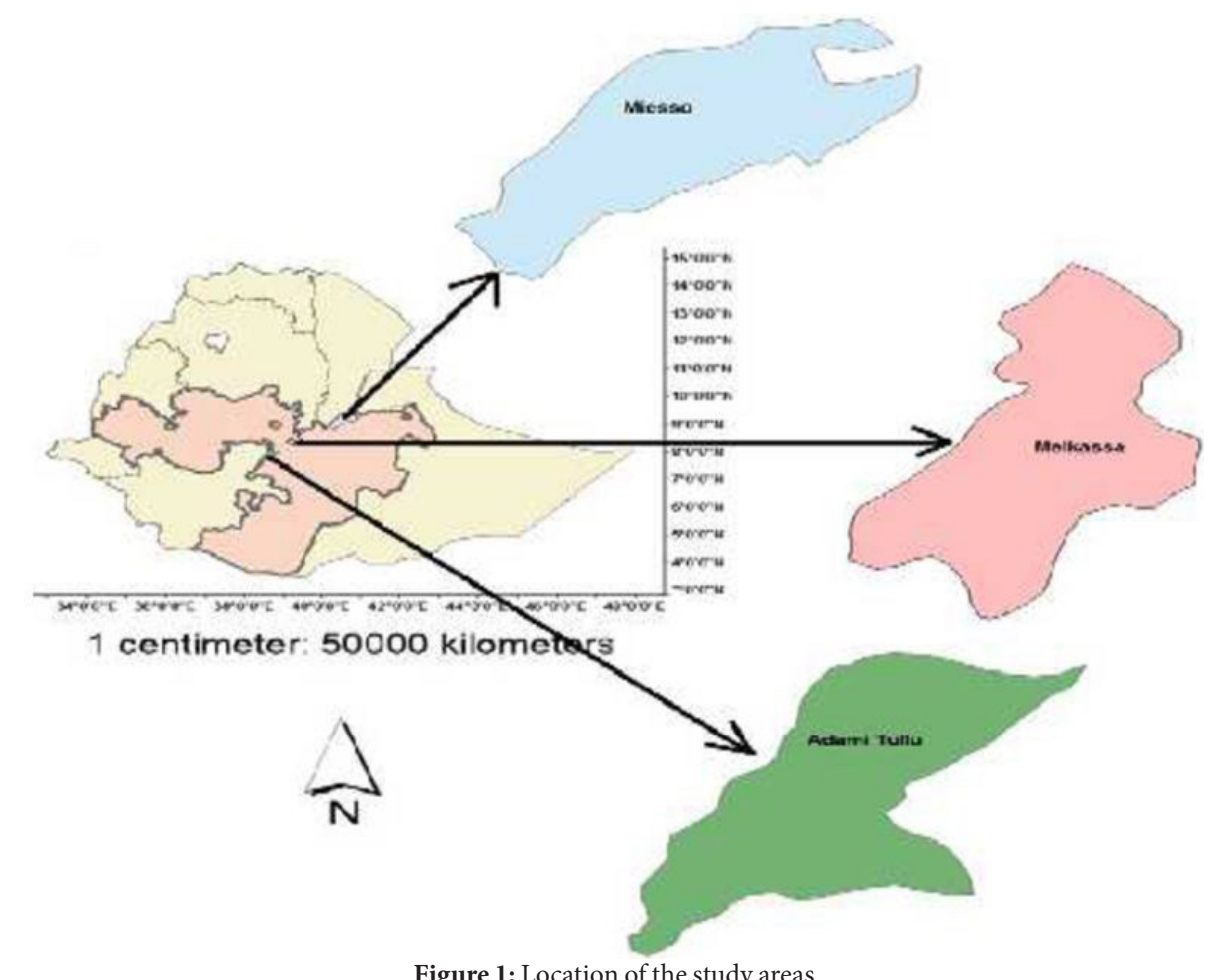

Figure 1: Location of the study areas

\section{Data sources and quality assessment}

The daily rainfall data of the three study areas are found in the Central Rift valley of Ethiopia. The characterization was based on ground observation data that were recorded for Melkassa agricultural Research Center (MARC)\#36 and Adami Tulu Agricultural Research Center (TARC)\#39, and Mieso \#39 meteorological stations since 1973. The whole dataset has the missing values less than $10 \%$. The characterization focused on determination of dates of the start, end and length of the growing season, and the number of rainy days using procedures described by Stern et al. (1982) [16]. INSTAT software v3.37 was used for analysis of the daily rainfall data. The data series was also examined for homogeneity using the cumulative deviation method and no heterogeneity was detected. Some missing and the outlier data were estimated using INSTAT+ v3.37 first order Markov-chain simulation model [17]. The main reason for choosing this model to fill the missing daily rainfall data is that it does not overstate the result and gives a more accurate model to each of the study areas as has been explained by NMSA (1996b) [18].

\section{Determination of start, end and length of the growing season}

The start of the rainy season (SOS) can be defined as the first occurrence of at least $20 \mathrm{~mm}$ rainfall totaled over 3 consecutive days $[16,17]$. This potential start can be a false start if an event, dry spell, occurs afterwards, as a dry spell of 9 days in the next 21 days. This paper also adopted this approach and the earliest start of season (SOS) was defined as the first occasion when the rainfall accumulated within a 3-day period reach was $20 \mathrm{~mm}$. Since the study areas exhibit a mono modal rainfall pattern (long rains during April-September), April 1st was taken as the earliest possible planting date for the study area. Accordingly, the potential starting date of the growing season was defined as the first occasion from April 1st that has at least 20 mm rainfall within a 3-day period.

End of the season an experimental evidence revealed the choice of $50 \%$ of water as the threshold for availability of water in soil for plant, for the crop water stress becomes severe when the available water drops below half of the crop water demand $50 \%(<0.5$ 
ETo) (Doorenbos and Kassam, 1979). Hence, the minimum required rainfall amount of a particular date of onset should be at least half of the amount of evapotranspiration (ETo) of that particular date.

The end of the season (EOS) was determined from rainfall-reference soil-water requirements relationship. The end of the season is the end of rainy season plus the time required to evapotranspire $100 \mathrm{~mm}$ of stored soil (Vertisols) water [16,17,19-21]. There was humid period, when ETo was less than the rainfall at the study areas. So, surplus stored soil water was available to continue the growing season beyond the end of the growing season (EOS). The procedure that we were used for the determining end of rainy season (EOS) was assumed to end after 1st September when 5-day cumulative rainfall was less than 0.5 of the soil -water availability. At the EOS the reference evapotranspiration was $5.5 \mathrm{~mm}$ day-1, $5.5 \mathrm{~mm}$ day-1 and 5.6 mm day-1 at Mieso, Melkassa and Adami Tulu, respectively. Therefore, the end of the growing season was extended by 18 days (100 mm/5.5 mm day-1), 18 days $(100 \mathrm{~mm} / 5.5 \mathrm{~mm}$ day-1) and 18 days $(100 \mathrm{~mm} / 5.6 \mathrm{~mm}$ day-1) at Mieso, Melkassa and Adami Tulu respectively.

Length of the growing season (LGS) is a key factor in deciding on the maturity of cultivars to be grown in dissimilar rainfall regimes [22]. Therefore, LGS was considered as the period from the start of the rain to the cessation of the growing season. It was calculated by subtracting the date of the beginning of the rainy season from the date of end of the growing season [23].

\section{Result and Discussion}

\section{Start of the growing season (SOS)}

Results of analysis of rainfall data at the three stations indicate that the growing season starts on May 26 at Mieso and Adami Tulu areas, and on May 27 at Melkassa area with a corresponding coefficient of variation (CV) of 31.3, 22.2, and 24.5\% respectively (Table 2). These dates correspond to $148^{\text {th }}$ and $149^{\text {th }}$ days of the year (DOY) at Mieso and Adami Tulu, and Melkassa areas, respectively. This indicates that the start of the growing season is late by a day at Melkassa area compared to the other two areas in the Central Rift Valley (CRV) of Ethiopia.

Nevertheless, the values of the coefficient of variation recorded at the three stations indicate the existence of high variability particularly at Mieso area.

The start of the season (SOS) rainfall in Mieso, Melkassa and Adami Tulu areas varied from September $11^{\text {th }}$ (257 DOY) to April $1^{\text {st }}$ (92 DOY), July $21^{\text {st }}\left(202\right.$ DOY) to April $1^{\text {st }}\left(92\right.$ DOY) and August $13^{\text {th }}$ (227 DOY) to April $1^{\text {st }}$ (92 DOY), respectively. The mean starting of growing season in Mieso, Melkassa and Adami Tulu has very high standard deviation (SD) of 46, 33 and 36 days, respectively, indicating that the SOS is not stable because the recorded standard deviations are out of the ranges suggested by Reddy (1990). The higher standard deviation of the SOS suggests that pattern could not be understood and, thus, decision pertaining to crop planting related activities will be with high risk.

The probability of occurrence of SOS once in four years (25\% percentile) corresponds to 102, 126 and 113 DOY at Mieso, Melkassa and Adami Tulu areas, respectively. Whereas the probability of occurrence of SOS twice in four years (50\%) corresponds to 137,152 and 155 and three times in four years also corresponds to 191, 177 and 180 DOY for Mieso, Melkassa and Adami Tulu, respectively

Therefore, earlier planting than on $102^{\text {th }}, 126^{\text {th }}$ and $113^{\text {th }}$ DOY is possible in Mieso, Melkassa and Adami Tulu once out of four years' time and also, earlier planting than $191^{\text {th }}$ (July 7), $177^{\text {th }}$ (June 24) and 180th (June 27) DOY is possible in three years every four years' time respectively. Moreover, the reliable planting date of mainly known cereal crops which is commonly grown in CRV, in particularly at and around Mieso, Melkassa and Adami Tulu ranges between 137-155 DOY (May 15 to June 2).

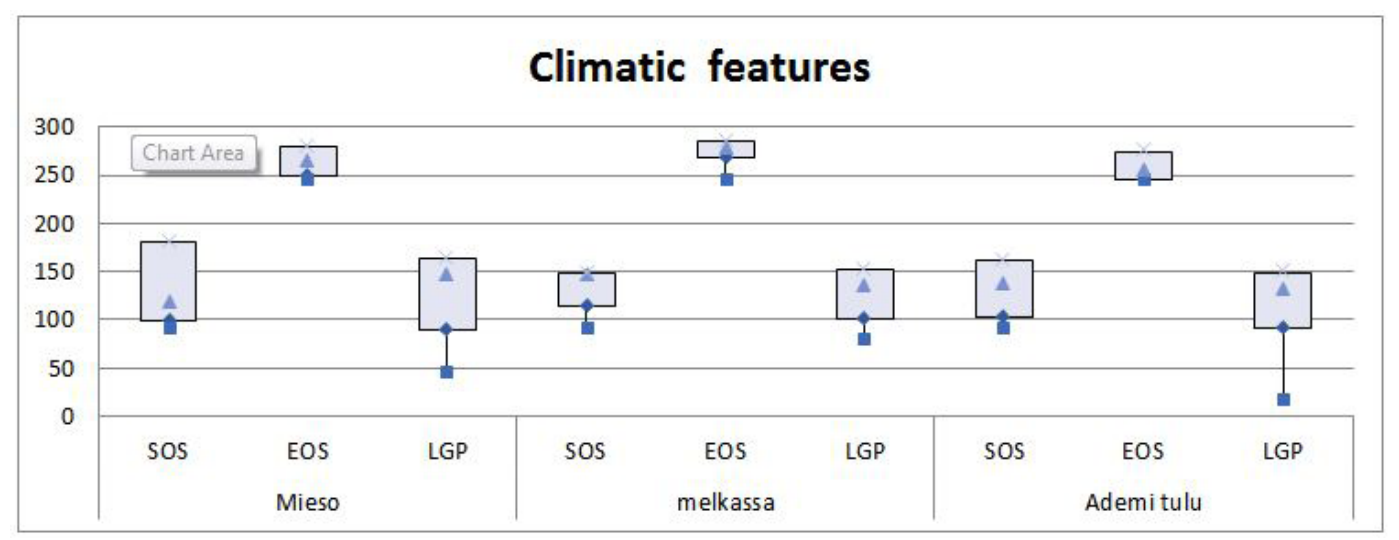

Figure 2: Climatic feature of Miesso, Melkassa and Adami Tulu

\section{End of the growing season (EOS)}

The end date of the season (EOS) falls on September $14^{\text {th }}$ at Mieso, October $1^{\text {st }}$ at Melkassa, and September $11^{\text {th }}$ at Adami Tulu areas 
with coefficient of variation of 5.7,4.7, and 4.9\%, respectively. The results indicate that the season comes to an end early at Adami Tulu area, followed by Mieso, while it is longer at Melkassa. The end dates of the season correspond to $259^{\text {th }}, 275^{\text {th }}$, and $256^{\text {th }} \mathrm{DOY}$ for Mieso, Melkassa, and Adami Tulu areas, respectively

The results of the rainfall analysis further indicate that there is a $25 \%$ chance once in four years that the end of the season will fall on $245^{\text {th }}$ and $269^{\text {th }}$ DOY at and around Mieso and Adami Tulu, and Melkassa areas, respectively. On the other hand, there is a $50 \%$ chance (twice in 4 years) for the end of the season to be on $255^{\text {th }}, 277^{\text {th }}$, and $250^{\text {th }}$ DOY at and around Mieso, Melkassa, and Adami Tulu areas, respectively. Also, the probability that the end of the season can be on $271^{\text {th }}, 285^{\text {th }}$, and 265 DOY for Mieso, Melkassa and Adami Tulu areas, respectively, is three times in four years or 75\%. At all the probability levels considered, the end of the season is extended more at Melkassa compared to Mieso and Adami Tulu area

\begin{tabular}{|c|c|c|c|c|c|c|c|c|}
\hline $\begin{array}{l}\text { Seasonal rainfall } \\
\text { Features }\end{array}$ & Minimum & $\begin{array}{l}\text { Quartile } 1 \\
\text { (25\%ile) }\end{array}$ & $\begin{array}{l}\text { Quartile 2 } \\
\text { (Median) }\end{array}$ & $\begin{array}{c}\text { Quartile } 3 \\
\text { (75\%ile) }\end{array}$ & $\begin{array}{c}\text { Maxi- } \\
\text { mum }\end{array}$ & Mean & S.D $( \pm)$ & C.V (\%) \\
\hline \multicolumn{9}{|c|}{ Mieso } \\
\hline SOS(DOY) & 92 & 102 & 137 & 191 & 257 & 148 & 46 & 31.3 \\
\hline EOS (DOY) & 245 & 245 & 255 & 271 & 292 & 259 & 14 & 5.7 \\
\hline LGS (No.of days) & 12 & 67 & 108 & 155 & 192 & 111 & 49 & 44.5 \\
\hline NRD ( day) & 92 & 92 & 92 & 99 & 165 & 99 & 14 & 14.9 \\
\hline \multicolumn{9}{|c|}{ Melkassa } \\
\hline SOS(DOY) & 92 & 126 & 152 & 177 & 202 & 149 & 33 & 22.2 \\
\hline EOS (DOY) & 245 & 269 & 277 & 285 & 306 & 275 & 15 & 4.7 \\
\hline LGS (No.of days) & 12 & 99 & 130 & 155 & 189 & 126 & 32 & 25.6 \\
\hline NRD ( day) & 92 & 92 & 84 & 99 & 147 & 97 & 10 & 10.3 \\
\hline \multicolumn{9}{|c|}{ Adami Tulu } \\
\hline SOS (DOY) & 94 & 113 & 155 & 180 & 227 & 148 & 36 & 24.5 \\
\hline EOS (DOY) & 245 & 245 & 250 & 265 & 290 & 256 & 12 & 4.9 \\
\hline LGS (No.of days) & 18 & 79 & 102 & 140 & 194 & 109 & 41 & 37.4 \\
\hline NRD (day). & 92 & 92 & 92 & 99 & 110 & 96 & 6 & 6.0 \\
\hline
\end{tabular}

Table 2: Descriptive statistics of important rainfall characteristics at Mieso, Melkassa and Adami Tulu weather stations .SOS = Start of season; DOY = day of the year; EOS = End of season; LGP = Length of growing period; NRD = Number of rainy days;

\section{Length of growing season (LGS) and number of rainy days}

Results of the analysis indicated that the mean length of growing season(LGS) for major cereal crop production in the main rainy season were 111,126 and 109 days at Mieso, Melkassa and Adami Tulu areas, respectively, (Table 2) with corresponding coefficient of variation $(\mathrm{CV})$ of $44.5,25.6$, and $37.5 \%$ (Table 2). The results indicate that the variability in the length of the growing season, as indicated by the variation of CV and standard deviation (SD), The highest variability of LGS was recorded at Miesso followed by Adami Tulu areas (Table 2). According the reports Kassie et al., (2014) in CRV, in particularly Ademi Tulu (Ziway) there were a variability of the length growing season it varied from 76 to 239 days [24].

The results obtained send a clear message that the LGP at the three stations is highly variable and, thus, needs a more cautions on planning and adoption of rainwater water harvesting scheme, improving water use efficiency, selecting varieties that are drought tolerant or early maturing, and using tillage practices that conserve soil moisture. If these are not put in place, the sustainability of crop production and, thus, the efforts of ensuring food security in the CRV of the country will be jeopardized.

Nevertheless, the results also confirm that major crops like maize varieties that require a LGP of less than 126 days can be produced with no risk in and around Mieso, Melkassa and Adami Tulu areas. However, varieties with more than 126 days cycle cannot be produced in the study areas using natural rainfall alone. On the other hand, growing maize varieties with 90 days cycle is also a waste of the growing period, for these 90 days are too short and result in wastage of 34 days of the growing period.

The mean number of rainy days at Mieso, Melkassa and Adami Tulu areas were 99, 97 and 97 with the coefficient of variation of 14.9, 10.3 and 6\%, respectively. The rainy days varied from 92 to 165, 92 to 147 and 92 to 110 at Mieso, Melkassa, and Adami Tulu, respectively. This indicates that there is high variability in number of the rainy days in semi-arid CRV of Ethiopia with high risk for successful crop production and livestock rearing due to the likely effect on pasture production and water scarcity.

The early onset date suggests that crop cultivars of the longer maturity type could do better with the late onset date [25]. The issue of LGS requires further due attention in that one needs to know the type and level of risks of yield loss associated with cultivars of different maturity categories, requiring different amounts of water during a sequence of growth stages. It is only then that one can confidently pinpoint the most suitable maturity cultivars to be planted in seasons with different onset date scenarios [25]. According to Borrell et al. (2003) pointed out that, such weather information guided farming can help in combining the genetic 
solutions into the management aspects, thus, providing farmers with a range of viable options to combat drought [26].

\section{Summery and Conclusion}

Among the rainfall parameters, date of start and end of the rainy season, length of the growing season were found to be the most variable climate-related events in CRV of Ethiopia The start of the season (SOS) rainfall in Mieso, Melkassa and Adami Tulu areas varied from April $1^{\text {st }}(92 \mathrm{DOY})$ to September $11^{\text {th }}(257 \mathrm{DOY})$, April $1^{\text {st }}(92 \mathrm{DOY})$ to July $21^{\text {st }}(202 \mathrm{DOY})$ and April $1^{\text {st }}(92 \mathrm{DOY})$ to August $13^{\text {th }}(227$ DOY) and also with high standard deviation (SD) of 46, 33 and 36 days, respectively. The end date of the season (EOS) falls on September 14th at Mieso, October 1st at Melkassa, and September $11^{\text {th }}$ at Adami Tulu areas with coefficient of variation of 5.7, 4.7, and $4.9 \%$, respectively. The analysis indicated that the mean length of growing season(LGS) for major cereal crop production in the main rainy season were 111,126 and 109 days at Mieso, Melkassa and Adami Tulu areas, respectively whereas, The mean number of rainy days at Mieso, Melkassa and Adami Tulu areas were 99, 97 and 97 with the coefficient of variation of 14.9, 10.3 and 6\%, respectively. The rainy days varied from 92 to 165, 92 to 147 and 92 to 110 at Mieso, Melkassa, and Adami Tulu, respectively

From the results obtained there might be a clear message that the SOS, EOS, LGP and number of rainy days at the three stations is highly variable and, thus, needs a more cautions on selection of crop variety with its drought tolerance or drought escaping and adoption of rainwater water harvesting scheme, improving water use efficiency, and using tillage practices that conserve soil moisture. Genetic, Environmental and management $\left(G^{\star} E^{\star} M\right)$ interaction are very crucial points in the study areas If these are not put in place, the sustainability of crop production and, thus, the efforts of ensuring food security in the CRV of the country will be jeopardized

\section{Acknowledgment}

I am also indebted to thanks the staff of Meteorology Research Division staff at Melkassa Agriculture Research Center for their great support in providing weather data's. Special thanks also go to. Journal of Horticultural science and Crop research for the accepting an article to publish and availing the information for the scientific community and the list but not last my great appreciations goes for the editor for his valuable comments and suggestion to improve the article more

\section{References}

1. Bewket W, Conway D (2007) A note on the temporal and spatial variability of rainfall in the drought-prone Amhara region of Ethiopia. Int J Clim 27: 1467-77.

2. USAID (2007) Adapting to climate variability and change. A guidance manual for development planning. Weather 64: 115-20.

3. International monetary fund (IMF) (2002) Ethiopian statistical Appendix Washington DC IMF country report no. 02/214.

4. World Bank (2002) The World Bank group, 2002. Country profile Table. Ethiopia Data Profile, World Bank.

5. Amekudzi LK, Yamba E, Preko K, Asare EO, Aryee J, et al. (2015) Variabilities in Rainfall Onset, Cessation and Length of Rainy Season for the Various AgroEcological Zones of Ghana. Ecological Impacts Climate Change 3: 416-34.

6. Owusu K, Waylen P (2009) Trends in Spatio-Temporal Variability in Annual Rainfall in Ghana (1951-2000). Weather 64: 115-20.

7. Ati OF, Stigter CJ, Olandipo EO (2002) A comparison of methods to determine the onset of the growing season in northern Nigeria. Int J Clim $22: 732-42$.

8. Raes D, Sithole A, Makarau A, Milford J (2004) Evaluation of first planting dates recommended by criteria currently used in Zimbabwe. Agric For Meteorol 125: $177-85$.

9. Kipkorir EC, Raes D, Bargerei RJ, Mugalvai EM (2007) Evaluation of two risk assessment methods for sowing maize in Kenya. Agric For Meteorol 144: 193-9.

10. Segele ZT, Lamb PJ (2005) Characterization and variability of Kiremt rainy season over Ethiopia. Meteorol Atmos Phys 89: 153-80.

11. Mugalavai EM, Emmanuel C, Kipkorir EC, Raes D, Rao MS (2008) Analysis of rainfall onset, cessation and length of growing season for western Kenya. Agric For Meteorol 148: 1123-35.

12. Demeke AB, Keil A, Zeller M (2011) Using panel data to estimate the effect of rainfall shocks on small holders food security and vulnerability in rural Ethiopia. Climatic Change 108: 185-206.

13. Perrin N, Mearns R, Kononen M, Kuriakose A, Agrawal A (2011) Costing Adaptation through Local

14. Rosell S (2011) Regional perspective on rainfall change and variability in the central highlands of Ethiopia, 1978-2007. App Geogr 31: 329-38.

15. Sorecha EM, Bayissa B, Toru T (2017) Characterization of Rainfall Indices for Crop Production in Kersa District, Eastern Ethiopia: Farmers' Advisory. Acad Res J Agri Sci Res 5: 134-9.

16. Stern RD, Dennett MD, Dale IC (1982) Analyzing daily rainfall measurements to giveagronomically useful results. I. Direct methods. Exper Agri 18: 223-36.

17. National Meteorological Agency (NMA) (2007) Climate Change National Adaptation Programme of Action (NAPA) of Ethiopia. Technical Report, United Nations Development Program (UNDP). Addis Abeba, Ethiopia: NMA.

18. Feyera Merga (2013) Evaluating Risks Associated With Dry Soil Planting Of Sorghum [Sorghum Bicolor (L.) Moench] And Maize (Zea Mays L.) At Different Depths In Less Predictable Onset Of Rain In The Central Rift Valley, Ethiopia M.Sc. Thesis submitted to school of Graduate Study, Hramaya University, Ethiopia.

19. Diga GM (2005) Using seasonal climate outlook to advice on sorghum production in the Central Rift Valley of Ethiopia. PhD thesis, Bloemfontein, Republic of South Africa.

20. Conway D, Schipper ELF (2011) Adaptation to climate change in Africa: challenges and opportunities identified from Ethiopia. Glob Environ Change 21: 22737.

21. Hellmuth ME, Moorhead A, Thomson MC, Williams J (2007) Climate Risk Management in Africa: Learning from Practice. New York: International Research Institute for Climate and Society, Columbia University.Institutions. Village Survey Results: Ethiopia. Washington,DC: World Bank. 
22. Mupangwa W, Walker S, Twomlow S (2013) Start, end and dry spell of the growing season in semi-arid southern Zimbabwe. J Arid Environ 75: 1097-104.

23. Kassie BT, Rötter RP, Hengsdijk H, Asseng S, Van Ittersum MK, et al. (2014) Climate variability and change in the Central Rift Valley of Ethiopia: challenges for rainfed crop production J Agri Sci 152: 58-74.

24. Stewart JI (1988) Response Farming in Rainfed Agriculture. The WHARF Foundation Press 103.

25. Borrell A, Oosterom EV, Graeme H, David J, Bob H (2003) Using science to combat drought: a case study of stay-green in sorghum. In: R. Stone and I. Partridge (Eds). Science for Drought. Proceedings of the National Drought Forum 120-3. 